\title{
PERANAN MAHASISWA FAKULTAS HUKUM SEBAGAI PELAKSANA BANTUAN HUKUM (LEGAL AID) KEPADA MASYARAKAT
}

\section{The Role of Law Faculty Students as Executor Legal Aid to Community}

\author{
Deni Achmad \\ Fakultas Hukum, Universitas Lampung \\ deni.achmad1981@gmail.com
}

\begin{abstract}
The role of law students in the implementation of legal aid is divided into two, namely the implementation of legal aid litigation and non-litigation legal aid. The role of students in the provision of legal aid services, urgent existence, considering many people who are not capable of, marginalized and legally blind in Indonesia is difficult to get access to justice, especially a dense population and spread across a wide area so it is not proportional to the number Advocates are available and include high student awareness of the legal issues faced by the community/communities are not able to. Students have contributed significantly in their communities by providing legal aid services, running the advocacy work and organizing in their communities in order to encourage growth is growing awareness of the laws of society and realize access to justice (acces to justice) for everyone, especially people not being able to obtain a guarantee in the fulfillment of their rights as citizens, especially equality before the law (equality before the law) as mandated by the constitution in Article 28D paragraph (1) and Article $28 \mathrm{H}$ paragraph (2) of the constitution of 1945.
\end{abstract}

Keywords: Student, Legal Aid, Role

\begin{abstract}
abstrak
Peranan mahasiswa hukum dalam pelaksanaan bantuan hukum terbagi dua yaitu dalam pelaksanaan bantuan hukum litigasi dan bantuan hukum non litigasi. Peran mahasiswa dalam pemberian layanan bantuan hukum, sangat urgen eksistensinya, mengingat masih banyaknya masyarakat yang tidak mampu, marjinal dan buta hukum di Indonesia yang sulit mendapatkan akses terhadap keadilan, apalagi jumlah penduduk yang padat dan menyebar di berbagai wilayah yang luas sehingga tidak sebanding dengan jumlah Advokat yang tersedia dan termasuk kepedulian mahasiswa yang tinggi terhadap permasalahan hukum yang dihadapi masyarakat/kelompok masyarakat tidak mampu. Mahasiswa telah berkontribusi secara nyata di komunitasnya dengan memberikan layanan bantuan hukum, menjalankan
\end{abstract}


kerja-kerja advokasi dan pengorganisasian di komunitasnya untuk dapat mendorong tumbuh berkembangnya kesadaran hukum masyarakat dan mewujudkan akses terhadap keadilan (acces to justice) bagi setiap orang terutama masyarakat tidak mampu agar memperoleh jaminan dalam pemenuhan haknya sebagai warga negara khususnya persamaan dihadapan hukum (equality before the law) sebagaimana amanat konstitusi dalam Pasal 28D ayat (1) dan Pasal 28H ayat (2) UUD 1945.

\section{Kata Kunci: Mahasiswa, Pelaksana Bantuan Hukum, Peran}

\section{A. Pendahuluan}

Bantuan hukum merupakan salah satu hal wajib yang harus dilakukan oleh setiap negara di dunia ini kepada rakyatnya terutama pada negara Indonesia sebagai negara hukum. Bantuan hukum merupakan jawaban atas permasalahan hukum yang dihadapi setiap warga negara, khususnya rakyat tidak mampu/kalangan tidak mampu. Bantuan hukum sendiri sebagaimana dimuat dalam Undang-Undang No.16 Tahun 2011 tentang Bantuan Hukum memiliki pengertian: jasa hukum yang diberikan oleh Pemberi Bantuan Hukum secara cuma-cuma kepada Penerima Bantuan Hukum. Penerima Bantuan Hukum sendiri adalah orang atau kelompok orang tidak mampu. Jaminan atas hak bantuan hukum merupakan implementasi dari prinsip persamaan dihadapan hukum (equality before the law) sebagaimana amanat konstitusi dalam Pasal 28D ayat (1) dan Pasal 28H ayat (2) UUD1945. Negara terutama pemerintah sebagai penyelenggaran negara memiliki tanggung jawab dalam pemenuhan hak atas bantuan hukum sebagai hak konstitusional warga negara. ${ }^{1}$ Berdasarkan pertimbangan inilah secara yuridis urgennya eksistensi Undang-Undang Bantuan Hukum.

Lahirnya Undang-Undang Nomor 16 Tahun 2011 tentang Bantuan Hukum, selanjutnya disebut Undang-Undang Bantuan Hukum adalah dalam rangka mewujudkan akses terhadap keadilan (access to justice) bagi setiap orang terutama orang tidak mampu atau tidak mampu agar memperoleh jaminan dalam pemenuhan haknya atas bantuan hukum ${ }^{2}$. Adanya kesadaran negara, dalam hal ini pemerintah untuk mengimplementasikan tanggung jawabnya melalui lahirnya Undang-Undang Bantuan Hukum, setidaknya menjadi salah satu peluang yang mesti dimanfaatkan dalam upaya

\footnotetext{
${ }^{1}$ Sebagaimana dijelaskan dalam bagian awal UU Bantuan Hukum, Menimbang: bahwa negara menjamin hak konstitusional setiap orang untuk mendapatkan pengakuan, jaminan, perlindungan, dan kepastian hukum yang adil serta perlakuan yang sama di hadapan hukum sebagai sarana perlindungan hak asasi manusia.

${ }^{2}$ J. Djohansjah, Makalah tentang Akses Menuju Keadilan (Access to Justice) Pelatihan Hak Asasi Manusia Untuk Jejaring Komisi Yudisial RI, Bandung, 30 Juni - 3 Juli 2010.
} 
mewujudkan akses terhadap keadilan, terlepas dari segala kelemahan dan kekurangan yang terdapat dalam Undang-Undang Bantuan Hukum.

Bantuan hukum diberikan oleh lembaga bantuan hukum atau organisasi kemasyarakatan yang memberi layanan bantuan hukum, yang meliputi menjalankan kuasa, mendampingi, mewakili, membela, dan/atau melakukan tindakan hukum lain untuk kepentingan hukum penerima bantuan hukum. Dalam pelaksanaannya, selanjutnya pemberi bantuan hukum diberikan hak melakukan rekrutmen terhadap Advokat, Paralegal, Akademisi, dan Mahasiswa Fakultas Hukum. Inilah bentuk legitimasi yuridis terhadap eksistensi mahasiswa dalam pemberian layanan bantuan hukum bagi masyarakat tidak mampu atau kelompok masyarakat tidak mampu yang berhadapan dengan masalah hukum.

Dengan adanya pengakuan secara yuridis terhadap eksistensi mahasiswa dalam Undang-Undang Bantuan Hukum ini, maka akan semakin memperkuat status maupun posisi mahasiswa dalam menjalankan peran dan tugasnya di komunitas, mengingat selama ini eksistensi Mahasiswa hanya memperoleh legitimasi sosial dari komunitasnya dan lembaga yang memberikan hak untuk beracara guna melakukan pembelaan dan pemberian layanan hukum, sehingga dalam menjalankan peran dan tugas mulianya seringkali Mahasiswa mendapat resistensi dari aparat penegak hukum maupun pemerintah.

Bila ditelusuri lebih jauh, terutama dilihat dari sejarah dan perkembangan mahasiswa pada dasarnya merupakan seseorang yang bukan sarjana hukum, tetapi mengetahui masalah hukum dan advokasi hukum. Mahasiswa sebagai Legal Asistant yang tugasnya membantu seorang legal yaitu pengacara (advokat) atau notaris dalam pemberian saran hukum kepada masyarakat dan bertanggung jawab langsung kepada legal. Untuk menjadi Legal Asistant diperlukan kualitas pendidikan tertentu, namun tidak dapat beracara atau mengesahkan suatu perbuatan hukum. Mahasiswa yang dalam hal ini aktif dalam pelaksanaan pemberian bantuan hukum dilahirkan melalui serangkaian pendidikan secara komprehensif dan berkelanjutan guna membangun kesadarannya, dengan harapan selanjutnya adalah mampu memperjuangkan pemenuhan hak-hak asasi dari komunitasnya melalui pemberian layanan bantuan hukum.

Sebelum lahirnya Undang-Undang Bantuan Hukum, istilah mahasiswa tidak ditemukan dalam satu-pun peraturan perundang-undangan di Indonesia. Meskipun demikian eksistensinya telah lama dikenal dan berkembang di komunitas masyarakat. Mahasiswa sendiri digagas dan dikembangkan oleh kalangan dari organisasi non pemerintah (nongovernment organization), diantaranya Yayasan Lembaga Bantuan Hukum Indonesia (YLBHI), sebagai salah satu lembaga Bantuan Hukum tertua di Indonesia, dengan memberikan berbagai bentuk pendidikan dan pelatihan 
hukum bagi masyarakat tidak mampu dan marjinal, sehingga mereka memiliki kemampuan dan keterampilan dalam memperjuangkan hakhaknya, sekaligus mampu memberikan layanan bantuan hukum di komunitasnya.

Peran mahasiswa dalam pemberian layanan bantuan hukum, sangat urgen eksistensinya, mengingat masih banyaknya masyarakat yang tidak mampu, marjinal dan buta hukum di Indonesia yang sulit mendapatkan akses terhadap keadilan, apalagi jumlah penduduk yang padat dan menyebar di berbagai wilayah yang luas sehingga tidak sebanding dengan jumlah Advokat yang tersedia dan termasuk kepedulian mahasiswa terhadap permasalahan hukum yang dihadapi masyarakat/kelompok masyarakat tidak mampu. Sementara selama ini mahasiswa telah berkontribusi secara nyata di komunitasnya dengan memberikan layanan bantuan hukum. Mahasiswa bahkan juga menjalankan kerja-kerja advokasi dan pengorganisasian di komunitasnya untuk dapat mendorong tumbuh berkembangnya kesadaran hukum masyarakat serta mampu mendorong proses demokrasi di tingkat lokal.

Namun tidak adanya legitimasi yuridis terhadap eksistensi mahasiswa selama ini senantiasa menjadi hambatan dan kendala bagi Mahasiswa dalam menjalankan peran dan tugasnya dalam pemberian layanan bantuan hukum, baik berupa legalitas yang seringkali dipertanyakan oleh berbagai pihak terutama aparat penegak hukum maupun pemerintah. Hal mana cenderung berujung pada resistensi terhadap mahasiswa sehingga mereka tidak dapat bekerja secara maksimal.

Setidaknya ada tiga tantangan yang harus dihadapi ke depan. Pertama, tentang bagaimana menjamin kapasitas mahasiswa sesuai dengan peran dan fungsinya, Kedua bagaimana membuat dan menjelaskan batas-batas kerja mahasiswa karena mahasiswa bukanlah sebuah pekerjaan atau profesi dan yang Ketiga mengenai mekanisme pengawasan terhadap mahasiswa.

Guna menghadapi tantangan di atas, maka kedepan mahasiswa harus memiliki kapasitas dan integritas yang kuat, sehingga kader-kader mahasiswa perlu mendapatkan pendidikan secara komprehensif dan berkelanjutan, baik mengenai pengetahuan hukum dasar, keterampilan maupun nilai etis seorang mahasiswa. Dengan demikian sangat perlu kiranya, lembaga pemberi bantuan hukum untuk segera mempersiapkan adanya lembaga pendidikan khusus bagi mahasiswa sebagai wadah untuk melahirkan advokat-advokat yang handal. Disamping itu, perlu dipertegas ruang lingkup atau batasan peran dan tugas mahasiswa agar tidak disalahartikan sebagai sebuah pekerjaan atau profesi.

Sedangkan berkaitan dengan pengawasan terhadap pelaksanaan kerjakerja mahasiswa di komunitasnya, mesti pula dipersiapkan secara baik melalui sebuah mekanisme, di samping tetap "membumikan" nilai-nilai etis 
(kode etik) bagi mahasiswa. Hal ini diperlukan guna untuk mengantisipasi terjadinya penyimpangan dan benturan kepentingan dalam pemberian layanan bantuan hukum. Sedangkan kode etik mahasiswa diperlukan sebagai pedoman bagi mahasiswa dalam menjalankan pemberian layanan bantuan hukum di komunitasnya, agar eksistensi mahasiswa semakin kuat dan mendapatkan kepercayaan dari semua pihak, termasuk aparat penegak hukum dan pemerintah dan terutama masyarakat.

Adanya kesadaran negara, dalam hal ini pemerintah untuk mengimplementasikan tanggung jawabnya melalui lahirnya Undang-Undang Bantuan Hukum, setidaknya menjadi salah satu peluang yang mesti dimanfaatkan dalam upaya mewujudkan akses terhadap keadilan, terlepas dari segala kelemahan dan kekurangan yang terdapat dalam Undang-Undang Bantuan Hukum.

Berdasarkan uraian latar belakang di atas, maka yang menjadi permasalahan dalam penelitian ini adalah 1) Bagaimanakah peranan mahasiswa dalam pelaksanaan bantuan hukum?; dan 2) Apakah yang menjadi faktor penghambat mahasiswa dalam pelaksanaan bantuan hukum?

Pendekatan masalah yang digunakan adalah yuridis normatif dan yuridis empiris. Narasumber penelitian terdiri dari pihak Penggerak Mahasiswa dalam Organisasi Bantuan Hukum (OBH), Pihak Pengurus OBH, Advokat dan akademisi Hukum Pidana Fakultas Hukum Universitas Lampung. Pengumpulan data dilakukan dengan studi pustaka dan studi lapangan, selanjutnya data dianalisis secara kualitatif.

\section{B. Pembahasan}

\section{Peranan Mahasiswa dalam Pelaksanaan Bantuan Hukum}

Peran adalah suatu sistem kaidah-kaidah yang berisikan patokanpatokan perikelakuan, pada kedudukan-kedudukan tertentu di dalam masyarakat, kedudukan mana dapat dipunyai pribadi ataupun kelompokkelompok pribadi dan berperannya pemegang peranan tadi, dapat sesuai atau mungkin berlawanan dengan apa yang ditentukan di dalam kaidah-kaidah ${ }^{3}$.

Suatu Peran dari Individu atau Kelompok dapat dijabarkan dalam beberapa bagian, yaitu ${ }^{4}$ :

a. peran yang ideal yaitu peran yang dijalankan oleh individu atau kelompok sesuai dengan ketentuan-ketentuan yang ditetapkan;

b. peran yang seharusnya yaitu peran yang memang seharusnya dijalankan oleh individu atau kelompok sesuai dengan kedudukannya;

\footnotetext{
${ }^{3}$ Soerjono Soekanto, Pokok-Pokok Sosiologi Hukum, (Jakarta: PT Raja Grafindo Persada, 2003), hlm. 139.

${ }^{4}$ Ibid., hlm. 140.
} 
c. peran yang dianggap diri sendiri yaitu peran yang dijalankan oleh diri sendiri karena kedudukannya dilakukan untuk kepentingannya; dan

d. peran yang sebenarnya telah dilakukan yaitu peran di mana individu atau kelompok itu memunyai kedudukan dan benar telah menjalankan peran sesuai dengan kedudukannya.

Berkaitan dengan penegakan hukum, peranan yang ideal dan peranan yang seharusnya adalah memang peranan yang dikehendaki dan diharapkan oleh hukum dan ditetapkan oleh Undang-Undang. Sedangkan peran yang dianggap diri sendiri dan peranan yang sebenarnya telah dilakukan adalah peran yang mempertimbangkan antara kehendak hukum yang tertulis dengan kenyataan-kenyataan, dalam hal ini kehendak hukum harus menentukan dengan kenyataan yang ada. Berdasarkan teori di atas, Soerjono Soekanto menarik pengertian ${ }^{5}$ :

a. peranan yang telah ditetapkan sebelumnya disebut sebagai peranan normatif, dalam penegakan hukum secara total enforcement, yaitu penegakan hukum yang bersumber pada substansi (Substantion of the Criminal Law);

b. peranan ideal dapat diterjemahkan sebagai peranan yang diharapkan dilakukan oleh pemegang peranan tersebut; dan

c. interaksi kedua peranan yang telah diuraikan di atas, akan membentuk peranan yang faktual yang dimiliki dalam menjalankan hukum dan Undang-Undang tersebut.

Bantuan hukum berasal dari kata "bantuan" yang berarti pertolongan dengan tanpa mengharapkan imbalan dan kata "hukum" yang mengandung pengertian keseluruhan kaidah atau norma mengenai suatu segi kehidupan masyarakat dengan maksud untuk menciptakan kedamaian. Apabila kita kaji lebih lanjut, pada dasarnya pemopuleran istiah "bantuan hukum" adalah sebagai terjemahan dari istilah legal aid dan legal assistance yang dalam praktik keduanya memunyai orientasi yang agak berbeda satu sama lain. Legal aid biasanya lebih digunakan untuk menunjukkan pengertian bantuan hukum dalam arti sempit berupa pemberian jasa di bidang hukum kepada seseorang yang terlibat dalam suatu perkara secara cuma-cuma atau gratis khususnya bagi mereka yang tidak mampu (tidak mampu), sedangkan legal assistance adalah bermakna pemberian jasa hukum oleh pemberi bantuan hukum dengan skala yang lebih luas tanpa membedakan apakah klien pengguna jasa hukum tersebut mampu atau tidak.

Pemberi bantuan hukum adalah lembaga bantuan hukum atau organisasi kemasyarakatan yang memberi layanan bantuan hukum yang diartikan secara yuridis menurut Pasal 1 angka 3 Undang- Undang Nomor 16 Tahun 2011 tentang Bantuan Hukum. Berdasarkan hal ini dapat diketahui

${ }^{5}$ Ibid., hlm. 141. 
bahwa pemberi bantuan hukum adalah Lembaga Bantuan Hukum atau organisasi kemasyarakatan, dengan demikian, perlu diketahui lebih lanjut mengenai Lembaga Bantuan Hukum atau organisasi kemasyarakatan dan juga advokat sebagai pemberi bantuan hukum. Memang tidak semua Lembaga Bantuan Hukum atau organisasi kemasyarakatan dalam konteks aturan ini yang bisa menjadi pemberi bantuan hukum. Di mana di dalam Pasal 8 ayat (1) dan ayat (2) Undang-Undang Nomor 16 Tahun 2011 tentang Bantuan Hukum disebutkan:

1) Pelaksanaan Bantuan Hukum dilakukan oleh Pemberi Bantuan Hukum yang telah memenuhi syarat berdasarkan UndangUndang ini.

2) Syarat-syarat Pemberi Bantuan Hukum sebagaimana dimaksud pada ayat (1) meliputi:

a. berbadan hukum;

b. terakreditasi berdasarkan Undang-Undang ini;

c. memiliki kantor atau sekretariat yang tetap;

d. memiliki pengurus; dan

e. memiliki program Bantuan Hukum.

Jadi, hanya pemberi bantuan yang memenuhi seluruh syarat diataslah yang dapat memberikan bantuan hukum kepada penerima bantuan hukum. Dalam Undang-Undang Nomor 16 Tahun 2011 tentang Bantuan Hukum di sebutkan bahwa penerima bantuan hukum adalah orang atau kelompok orang tidak mampu, definisi tersebut di jelaskan di dalam Undang-Undang Nomor 16 Tahun 2011 tentang Bantuan Hukum. Koalisi Untuk Bantuan Hukum (KUBAH) dalam Draft Rancangan Undang-Undang Bantuan Hukum versi KUBAH sebelum Undang-Undang ini ditetapkan mengusulkan agar definisi penerima bantuan hukum tidak semata-mata hanya diterjemahkan orang yang tidak mampu secara ekonomi, namun juga orang atau kelompok yang termarjinalkan karena suatu kebijakan publik; Orang atau kelompok yang hak-hak sipil dan politiknya terabaikan; Komunitas masyarakat adat; perempuan dan penyandang cacat hingga mereka para korban pelanggaran hak-hak dasar seperti penggusuran dan lain-lain. ${ }^{6}$

Pemberian bantuan hukum bagi orang-orang yang tidak mampu dimaksudkan sebagai suatu cara untuk memperbaiki ketidakseimbangan sosial. Seseorang yang mengajukan permohonan untuk mendapatkan bantuan hukum, harus menunjukkan bukti-bukti tentang ketidakmampuannya, misalkan dengan memperlihatkan suatu pernyataan dari Lurah yang disahkan Camat, mengenai penghasilannya yang rendah

\footnotetext{
${ }^{6}$ Jurnalis Kompasiana, Mengurai UU Bantuan Hukum, http://hukum.kompasiana.com/2012 /08/08/mengurai-uu-bantuan-hukum-3-483692.html, (diakses pada tanggal 10 Agustus 2014 pukul 19.30 WIB).
} 
atau orang tersebut sama sekali tak berpenghasilan dan keteranganketerangan lain yang berhubungan dengan ketidakmampuan.

Bantuan hukum juga memiliki tiga unsur didalamnya, unsur-unsur dalam bantuan hukum yaitu antara lain: ${ }^{7}$

a. Adanya Jasa Hukum

Adanya jasa hukum adalah pemberian bantuan diberikan dalam ruang lingkup permasalahan hukum yang dialami oleh orang yang membutuhkan bantuan karena keterlibatannya dalam masalah hukum sedangkan orang tersebut kurang mengerti hukum atau kurang mengetahui hukum dan termasuk orang yang tidak mampu dalam segi keuangan.

b. Tindakan untuk menjadi pembela/kuasa di luar maupun di dalam pengadilan.

Tindakan yang dilakukan oleh pemberi bantuan hukum berupa pembelaan- pembelaan yang dilakukan sebagai pembela/penasehat hukum dalam perkara pidana yang dilakukan mulai dari tingkat kepolisian, kejaksaan maupun pengadilan. Tindakan yang dilakukan oleh pemberi bantuan hukum dalam penanganan perkara perdata/tata usaha negara untuk menjadi kuasa guna mewakili, bertindak untuk dan atas nama serta guna kepentingan orang yang membutuhkan bantuan hukum baik di dalam maupun di pengadilan.

c. Adanya nasehat -nasehat hukum/konsultan hukum.

Adanya nasehat-nasehat hukum adalah pemberi bantuan hukum memberikan nasehat, pertimbangan, pengertian dan pengetahuan hukum kepada orang yang membutuhkan bantuan hukum terhadap permasalahanpermasalahan hukum yang sedang dihadapi. Bantuan hukum diberikan kepada orang yang tidak mampu tetapi jangan diartikan hanya sebagai bentuk belas kasihan kepada yang lemah semata. Seharusnya selain membantu orang tidak mampu, bantuan hukum juga merupakan gerakan moral yang memperjuangkan hak asasi manusia juga untuk mewujudkan cita-cita negara kesejahteraan (welfare state) dan keadilan sosial.

Selain bantuan hukum memiliki unsur-unsur tersebut, bantuan hukum juga memiliki tujuan program bantuan hukum, di mana program bantuan tersebut adalah:

a. menjamin dan memenuhi hak bagi penerima bantuan hukum (tidak mampu) untuk mendapatkan akses keadilan;

b. mewujudkan hak konstitusional segala warga negara sesuai dengan prinsip persamaan kedudukan di dalam hukum;

c. menjamin kepastian penyelenggaraan bantuan hukum dilaksanakan secara merata di seluruh wilayah Negara Republik Indonesia; dan

\footnotetext{
${ }^{7}$ Lasdin Wlas, Cakrawala Advokat Indonesia, (Yogyakarta: Liberty, 1989), hlm. 199.
} 
d. mewujudkan peradilan yang efektif, efisien, dan dapat dipertanggungjawabkan.

Tujuan Program Bantuan hukum ini terdapat di Pasal 3 UndangUndang Nomor 16 Tahun 2011 tentang Bantuan Hukum dan tujuan program bantuan hukum ini juga berkaitan dengan dua aspek, yaitu:

a. Aspek Kemanusiaan

Tujuan dari program bantuan hukum ini adalah untuk meringankan beban (biaya) hukum yang harus ditanggung oleh masyarakat tidak mampu di depan pengadilan, dengan demikian ketika masyarakat golongan tidak mampu berhadapan dengan proses hukum di pengadilan, mereka tetap memperoleh kesempatan untuk memperoleh pembelaan dan perlindungan hukum.

b. Aspek Peningkatan Kesadaran Hukum

Tujuan aspek kesadaran hukum, diharapkan bahwa program bantuan hukum ini akan memacu tingkat kesadaran hukum masyarakat ke jenjang yang lebih tinggi lagi. Dengan demikian, apresiasi masyarakat terdapat hukum akan tampil melalui sikap dan perbuatan yang mencerminkan hak dan kewajiban secara hukum. ${ }^{8}$

Pemberian bantuan hukum haruslah tepat sasaran. Dalam artian bahwa orang yang mendapatkan bantuan hukum, sebagaimana tujuan dari pemberian bantuan hukum itu harus orang-orang yang sesuai dengan kriteria yang dimaksud dalam undang-undang. Menurut Pasal 5 Undang-undang Bantuan Hukum, yang berhak mendapatkan bantuan hukum yaitu sebagai berikut:

a. penerima bantuan hukum sebagaimana dimaksud dalam Pasal 4 ayat (1) meliputi setiap orang atau kelompok tidak mampu yang tidak dapat memenuhi hak dasar secara layak dan mandiri.

b. hak dasar sebagaimana dimaksud pada ayat (1) meliputi hak atas pangan, sandang, layanan kesehatan, layanan pendidikan, pekerjaan dan berusaha, dan/atau perumahan.

Dalam undang-undang bantuan hukum, subjek penerima bantuan hukum tidak disebutkan secara jelas. Namun, pada prinsipnya harus mengacu pada ketentuan sebagaimana yang dimaksudkan di dalam Pasal 5 Undang-Undang Bantuan Hukum tersebut. Sehingga secara menyeluruh, kriteria subjek penerima bantuan hukum adalah sebagai berikut:

a. orang yang memiliki masalah hukum keperdataan, pidana, dan tata usaha negara, baik litigasi maupun non litigasi (mengacu pada pasal 4 undangundang bantuan hukum);

\footnotetext{
${ }^{8}$ Adnan Buyung Nasution, Bantuan Hukum di Indonesia, (Jakarta: LP3ES, 1988), hlm. 6-7.
} 
b. orang-orang yang hak-hak konstitusionalnya dilanggar oleh oknum penegak hukum;

c. orang-orang yang tidak mendapatkan akses untuk mendapatkan keadilan; dan

d. orang-orang yang teraniaya oleh karena masalah hukum yang sedang dihadapinya.

Jaminan atas hak bantuan hukum merupakan implementasi dari prinsip persamaan dihadapan hukum (equality before the law) sebagaimana amanat konstitusi dalam Pasal 28D ayat (1) dan Pasal 28H ayat (2) UUD1945. Negara terutama pemerintah sebagai penyelenggaran negara memiliki tanggung jawab dalam pemenuhan hak atas bantuan hukum sebagai hak konstitusional warga negara. Berdasarkan pertimbangan inilah secara yuridis urgennya eksistensi Undang-Undang Bantuan Hukum karena melihat lahirnya Undang-Undang Nomor 16 Tahun 2011 tentang Bantuan Hukum, selanjutnya disebut Undang-Undang Bantuan Hukum, sebagai mewujudkan akses terhadap keadilan (acces to justice) bagi setiap orang terutama orang tidak mampu atau tidak mampu agar memperoleh jaminan dalam pemenuhan haknya atas bantuan hukum.

Selain bantuan hukum memiliki unsur-unsur tersebut, bantuan hukum juga memiliki tujuan program bantuan hukum, di mana program bantuan tersebut adalah:

a. menjamin dan memenuhi hak bagi penerima bantuan hukum (tidak mampu) untuk mendapatkan akses keadilan;

b. mewujudkan hak konstitusional segala warga negara sesuai dengan prinsip persamaan kedudukan di dalam hukum;

c. menjamin kepastian penyelenggaraan bantuan hukum dilaksanakan secara merata di seluruh wilayah Negara Republik Indonesia; dan

d. mewujudkan peradilan yang efektif, efisien, dan dapat dipertanggungjawabkan.

Bantuan hukum diberikan oleh lembaga bantuan hukum atau organisasi kemasyarakatan yang memberi layanan bantuan hukum, yang meliputi menjalankan kuasa, mendampingi, mewakili, membela, dan/atau melakukan tindakan hukum lain untuk kepentingan hukum penerima bantuan hukum. Dalam pelaksanaannya, selanjutnya pemberi bantuan hukum diberikan hak melakukan rekrutmen terhadap Advokat, Mahasiswa, Akademisi, dan Mahasiswa Fakultas Hukum. Inilah bentuk legitimasi yuridis terhadap eksistensi Mahasiswa dalam pemberian layanan bantuan hukum bagi masyarakat tidak mampu atau kelompok masyarakat tidak mampu yang berhadapan dengan masalah hukum.

Dengan adanya pengakuan secara yuridis terhadap eksistensi Mahasiswa dalam Undang-Undang Bantuan Hukum ini, maka akan semakin memperkuat status maupun posisi Mahasiswa dalam menjalankan peran dan 
tugasnya di komunitas, mengingat selama ini eksistensi Mahasiswa hanya memperoleh legitimasi sosial dari komunitasnya.

Dengan adanya pengakuan secara yuridis terhadap eksistensi Mahasiswa dalam Undang-Undang Bantuan Hukum ini, maka akan semakin memperkuat status maupun posisi Mahasiswa dalam menjalankan peran dan tugasnya di komunitas, mengingat selama ini eksistensi Mahasiswa hanya memperoleh legitimasi sosial dari komunitasnya. Dalam pelaksanaan di lapangan. Peranan Mahasiswa sangat banyak. Menurut Batinta ${ }^{9}$, peranan mahasiswa dalam hal ini di dalam Organisasi Bantuan Hukum Bidang Konsultasi dan Bantuan Hukum (BKBH) Universitas Lampung terbagi dua yaitu dalam pelaksanaan bantuan hukum litigasi dan bantuan hukum non litigasi.

Dalam bantuan hukum litigasi, mahasiswa memunyai peranan seperti paralegal, yaitu menjadi asisten dari advokat dan Akademisi yang melakukan kegiatan pendampingan litigasi di pengadilan. Mahasiswa tersebut memunyai tugas untuk mengawasi serta menyiapkan berkas-berkas perkara, mencatat agenda persidangan, menemui terdakwa serta berkomunikasi dengan terdakwa di tempatnya ditahan, serta hal-hal lainnya yang diperlukan untuk menunjang berjalannya pelaksanaan bantuan hukum dengan baik. Dalam bantuan hukum non litigasi, mahasiswa memunyai kegiatan-kegiatan yang cukup beragam, antara lain: penyuluh dalam kegiatan penyuluhan hukum, anggota tim dalam suatu penelitian hukum, konsultan dalam memberikan konsultasi hukum dan banyak kegiatan lainnya.

Menurut Sukriadi Siregar ${ }^{10}$, mahasiswa adalah penggerak utama dalam pelaksanaan bantuan hukum. Terkadang seorang advokat tidak dapat membagi waktunya untuk dapat fokus melaksanakan kegiatan bantuan hukum, dikarenakan advokat juga melaksanakan kegiatan legal service (jasa hukum) di luar kegiatan bantuan hukum, yang mana advokat mendapatkan honorarium secara profesional/ professional fee.

Hal ini turut dibenarkan oleh Dita Febrianto ${ }^{11}$, yang mengatakan seorang Akademisi fakultas hukum juga akan menghadapi kendala yang sama seperti advokat, dikarenakan seorang Akademisi memunyai tugas utama berdasarkan Tri Dharma Dikti, yaitu: Pengajaran, Pengabdian, dan Penelitian. Sehingga apabila seorang Akademisi diberikan kewajiban untuk melaksanakan Tri Dharma Dikti, dan ternyata berbarengan dengan kegiatan pelaksanaan bantuan hukum, maka Akademisi harus melaksanakan

\footnotetext{
${ }^{9}$ Penggerak Mahasiswa dalam OBH Bidang Konsultasi dan Bantuan Hukum (BKBH) FH Unila

${ }^{10}$ Advokat dan Penggerak Bantuan Hukum di Provinsi Lampung.

${ }^{11}$ Akademisi dan Pengurus OBH Bidang Konsultasi dan Bantuan Hukum (BKBH) FH Unila
} 
kewajibannya terlebih dahulu, sehingga dapat mengenyampingkan pelaksanaan bantuan hukum tersebut ke paralegal dan mahasiswa.

\section{Faktor Penghambat Mahasiswa dalam Pelaksanaan Pemberian Bantuan Hukum}

Suatu organisasi di bidang hukum selalu tidak lepas dari yang namanya faktor penghambat, ada saja yang menjadi hambatan walaupun hanya sedikit atau sebesar batu kerikil karena pada hakikatnya tidak ada sesuatu yang berjalan dengan lancar-lancar saja. Menurut Soerjono Soekanto yang menyatakan dalam bukunya bahwa:

Gangguan terhadap lembaga penegakan hukum mungkin terjadi apabila ada ketidakserasian antara nilai, kaidah, dan pola perilaku. Gangguan tersebut terjadi apabila terjadi ketidakserasian antara nilai-nilai yang berpasangan yang menjelma di dalam kaidahkaidah yang bersimpang siur dan pola perilaku tidak terarah yang mengganggu kedamaian pergaulan hidup. ${ }^{12}$

Atas dasar yang telah dijelaskan oleh Soerjono Soekanto di atas, maka berikut ini adalah faktor-faktor yang dapat mempengaruhi mahasiswa dalam menjalankan perannya memberikan peranan dalam pelaksanaan bantuan hukum terdapat beberapa faktor-faktor penghambat, yakni antara lain ${ }^{13}$ :

\section{a. Faktor Hukumnya Sendiri}

Awal perkembangan hukum di Indonesia tidak adanya peraturan perundang-undangan bahwa mahasiswa dapat melakukan pemberian dan pelaksanaan bantuan hukum. Tidak adanya legitimasi yuridis terhadap eksistensi mahasiswa menjadi hambatan dan kendala bagi Mahasiswa dalam menjalankan peran dan tugasnya dalam pemberian layanan bantuan hukum, baik berupa legalitas yang seringkali dipertanyakan oleh berbagai pihak terutama aparat penegak hukum maupun pemerintah. Hal mana cenderung berujung pada resistensi terhadap mahasiswa sehingga mereka tidak dapat bekerja secara maksimal.

Dengan adanya peraturan perundang-undangan yang memberikan legitimasi yuridis kepada mahasiswa dengan melalui Undang-Undang Nomor 16 Tahun 2011 tentang Bantuan Hukum, mahasiswa dapat melaksanakan keilmuan dan praktek beracara melalui lembaga-lembaga bantuan hukum guna melaksanakan amanat Undang-Undang Dasar 1945 diatur dalam Pasal 28D ayat (1), yang mengatakan:

12 Soerjono Soekanto. Faktor-Faktor yang Memperngaruhi Penegakan Hukum. (Jakarta: Rajawali Pers, 1993), hlm. 7.

${ }^{13}$ Ibid., hlm. 8. 
"setiap orang berhak atas pengakuan, jaminan, perlindungan dan kepastian hukum yang adil serta perlakuan yang sama di hadapan hukum."

Selain itu, berdasarkan hasil wawancara dengan Dita Febrianto menerangkan bahwa dalam penjelasan Pasal 18 Undang-Undang Nomor 11 Tahun 2012 tentang Sistem Peradilan Pidana Anak dijelaskan bahwa paralegal, Akademisi dan mahasiswa fakultas hukum berhak memberikan bantuan hukum. Hal perbedaan pandangan inilah yang menjadi salah satu faktor penghambat untuk Bidang Konsultasi dan Bantuan Hukum Fakultas Hukum Universitas Lampung dalam memberikan bantuan hukum. ${ }^{14}$

Secara konstitusional bahwa hak hukum setiap warga Negara Indonesia dijamin oleh Negara. Sehingga seharusnya setiap orang yang tersandung oleh kasus maupun persoalan-persoalan hukum seyogyanya mendapatkan perlindungan hukum atau pendampingan hukum dalam masalah hukum yang sedang dihadapinya. Dalam praktik pelaksanaan pemberian bantuan hukum, pada prinsipnya seorang tersangka atau terdakwa berhak untuk mendapatkan bantuan hukum, sebagaimana yang tercantum dalam Pasal 54 Undang-undang Nomor 8 tahun 1981 tentang Acara Pidana, yaitu:

"guna kepentingan pembelaan, tersangka atau terdakwa berhak mendapat bantuan hukum dari seorang atau lebih penasehat hukum selama dalam waktu dan pada setiap tingkat pemeriksaan, menurut tatacara yang ditentukan dalam undang-undang ini."

\section{b. Faktor Penegak Hukum, yakni Pihak-Pihak yang Membentuk maupun yang Menerapkan Hukum}

Penegak hukum yang dimaksud dalam pelaksanaan pemberian bantuan hukum yaitu advokat, paralegal, Akademisi dan mahasiswa. Namun untuk advokat dalam memberikan bantuan hukum kepada masyarakat tidak mampu sangat sedikit ditemukan, karena dalam memberikan bantuan hukum, masyarakat tidak dapat memberikan bayaran layaknya royalti sebesar yang disetujui antara klien dan advokat professional (pengacara). Dan juga selain alasan terebut, menurut Sukriadi Siregar bahwa memang tidak dipungkiri penolakan terhadap pemberian bantuan hukum dalam suatu organisasi bantuan hukum sering juga mengalami penolakan, hal itu dikarenakan masih ada hakim yang berpandangan bahwasanya hanya seorang advokatlah yang telah diambil sumpah di Pengadilan Tinggi yang

${ }^{14}$ Berdasarkan hasil wawancara dengan Dita Febrianto di Fakultas Hukum Unila, 02 September 2015 pukul 11.00 wib. 
dapat membela di persidangan sebagaimana yang diatur oleh Pasal 4 Ayat (1) Undang-Undang Nomor 18 Tahun 2003 tentang Advokat, ${ }^{15}$ yaitu:

"Sebelum menjalankan profesinya, Advokat wajib bersumpah menurut agamanya atau berjanji dengan sungguh-sungguh di sidang terbuka Pengadilan Tinggi di wilayah domisili hukumnya".

Sedangkan mahasiswa dipandang masyarakat belum mampu melakukan bantuan hukum secara cakap dan baik, dikarenakan pandangan masyarakat yang memandang bahwa mahasiswa sedang menyelesaikan masa studinya dan belum memiliki surat izin beracara.

\section{c. Faktor Sarana atau Fasilitas yang Mendukung Pemberian Bantuan Hukum Hukum}

Sarana atau fasilitas juga merupakan faktor penghambat bagi mahasiswa dalam memberikan bantuan hukum. Kurangnya sarana atau fasilitas yang dimiliki mahasiswa berpengaruh terhadap pelaksanaan pemberian bantuan hukum kepada masyarakat tidak mampu. Menurut pendapat Dita Febrianto, bahwa dana yang dikeluarkan oleh mahasiswa fakultas hukum untuk terjun ke lapangan terkadang merupakan dana dari mahasiswa itu sendiri, bahkan terkadang pemberian dana oleh Negara kepada organisasi bantuan hukum dilakukan dengan sistem Reimburse atau bermakna mengganti uang yang sudah dikeluarkan untuk sesuatu pembayaran sehingga organisasi bantuan hukum terpaksa harus mengeluarkan dana talangan yang telah ditalangi oleh atau dari pihak badan hukum yang menaungi mahasiswa tersebut. ${ }^{16}$

\section{d. Faktor Masyarakat Sebagai Objek Pemberian Bantuan Hukum}

Pandangan masyarakat yang masih melihat bahwasanya seorang advokatlah atau pengacara yang sudah memiliki kantor hukum yang dapat memberikan bantuan hukum, hal ini tidak terlepas dari kurangnya sosialisasi kepada masyarakat mengenai Bidang Konsultasi dan Bantuan Hukum, sehingga kurangnya kepercayaan masyarakat kepada mahasiswa dalam hal bantuan hukum, dikarenakan pandangan masyarakat kepada mahasiswa terhadap permasalahan-permasalahan konflik tawuran dan kekerasan yang seringkali dilakukan oleh sekumpulan mahasiswa. Kurangnya kepercayaan terhadap pemberian bantuan hukum oleh mahasiswa juga disebabkan kurangnya kedekatan masyarakat tidak mampu dengan mahasiswa. Dan

15 Berdasarkan hasil wawancara dengan Sukriadi Siregar di Fakultas Hukum Unila, 04 September 2015 pukul 10.00 WIB.

${ }_{16}$ Berdasarkan hasil wawancara dengan Dita Febrianto di Fakultas Hukum Unila 05 September 2015, pukul 11.00 WIB. 
anggapan masyarakat yang memandang bahwa mahasiswa sedang menyelesaikan masa studinya dan belum memiliki surat izin beracara.

\section{e. Faktor Sosial Budaya}

Kebudayaan hukum pada dasarnya mencakup nilai-nilai yang mendasari hukum yang berlaku, nilai-nilai mana merupakan konsepsikonsepsi abstrak mengenai apa yang dianggap buruk. Nilai-nilai tersebut lazimnya merupakan pasangan nilai-nilai yang mencerminkan dua keadaan ekstrim yang harus diserasikan. Hal itulah yang dijadikan indikator di dalam penegakan hukum

Pandangan sikap yang melekat dan telah membudaya di dalam lingkungan masyarakat tidak mampu tentang mahalnya bantuan hukum menyebabkan sulitnya mahasiswa dalam memberikan kepercayaan kepada masyarakat tidak mampu. Mahasiswa dalam melakukan pengabdian sosial tentang bantuan hukum kepada masyarakat tidak mampu khususnya dilakukan dahulu sosialisasi dan pendekatan langsung, sehingga dapat menimbulkan kepercayaan dan sikap positif terhadap permasalahanpermasalahan hukum.

\section{Penutup}

Mahasiswa Fakultas Hukum dapat melaksanakan keilmuan dan praktek beracara melalui lembaga-lembaga bantuan hukum guna melaksanakan amanat Undang-Undang Dasar 1945 diatur dalam Pasal 28D ayat (1), berdasarkan Undang-Undang Nomor 16 Tahun 2011 tentang Bantuan Hukum.

Faktor-faktor yang dapat mempengaruhi mahasiswa dalam menjalankan perannya memberikan peranan dalam pelaksanaan bantuan hukum dapat ditanggulangi dengan adanya peraturan yang lebih menjelaskan secara terperinci tentang peran mahasiswa dalam beracara sehingga mendapatkan kepercayaan dari masyarakat untuk menangani suatu perkara pidana dengan di fasilitasi oleh suatu $\mathrm{OBH}$.

\section{Daftar Pustaka}

\section{A. Buku-buku}

Alfian, Melly Tan dan Selo Sumardjan, 1980, Ketidak mampuan Struktural:

Suatu Bunga Rampai, Jakarta: Yayasan Ilmu-Ilmu Sosial.

Atmasasmita, Romli, 1996, Sistem Peradilan Pidana Perspektif Eksistensialisme dan Abolisionisme, Bandung: Bina Cipta. 
Djohansjah, J. 2010. Makalah tentang Akses Menuju Keadilan (Access to Justice). Pelatihan Hak Asasi Manusia Untuk Jejaring Komisi Yudisial RI. Bandung.

Nasution, Adnan Buyung, 1988, Bantuan Hukum di Indonesia, Jakarta: LP3ES.

Nawawi Arief, Barda, 1983, Hukum Pidana dan Perkembangan Masyarakat, Bandung: Sinar Baru. , 1996, Bunga Rampai Kebijakan Hukum Pidana, Bandung: Citra Aditya Bakti.

Soekanto, Soerjono, 1993, Faktor-Faktor yang Memperngaruhi Penegakan Hukum, Jakarta: Rajawali Pers.

Grafindo Persada. , 2003, Pokok-Pokok Sosiologi Hukum, Jakarta: PT Raja

Sudarto, 1981, Kapita Selekta Hukum Pidana, Bandung: Alumni.

Widhayanti, Erni, 1988, Hak-Hak Tersangka/Terdakwa Di Dalam KUHAP, Yogyakarta: Liberty.

Wlas, Lasdin, 1989, Cakrawala Advokat Indonesia, Yogyakarta: Liberty.

B. Peraturan Perundang-undangan

Undang-Undang Dasar 1945

Undang-Undang Nomor 16 Tahun 2011 tentang Bantuan Hukum

Undang-Undang Nomor 18 Tahun 2003 tentang Advokat

\section{Sumber Lain}

Jurnalis Kompasiana, Mengurai UU Bantuan Hukum, 10 Agustus 2014, http://hukum.kompasiana.com/2012/08/08/mengurai-uu-bantuanhukum-3-483692.html 